
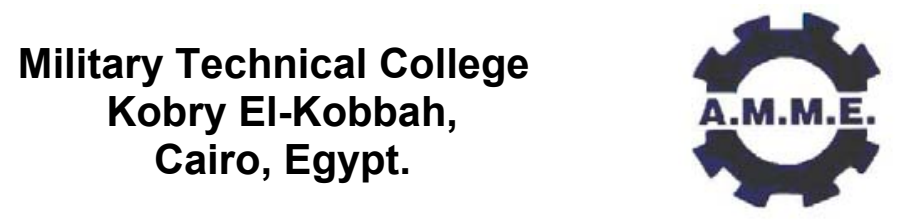
$13^{\text {th }}$ International Conference on Applied Mechanics and Mechanical Engineering.

\title{
MATERIAL FLOW IN FLEXIBLE MANUFACTURING
}

KOŠŤÁL ${ }^{*} P$., MUDRIKOVÁ ${ }^{* *} A$. and VELÍŠEK ${ }^{* * *} K$.

\begin{abstract}
The flexible manufacturing system contains some CNC machine tools supported by industrial robot for material handling. This system is designed to manufacturing a group of similar workpieces. The system is characterized by its internal material and information flow. The manufacturing process represents a complex dynamical process included technological, manipulation and control operations.
\end{abstract}

\section{KEY WORDS}

Material flow, Information flow, Flexible manufacturing, Automation

Assoc. Prof., Institute of Production Systems and Applied Mechanics, Slovak University of Technology, Rázusova 2, 91701 Trnava, Slovak Republic

** Senior lecturer, Institute of Production System and Applied Mechanics, Slovak University of Technology, Rázusova 2, 91701 Trnava, Slovak Republic

*** Full professor, Institute of Production Systems and Applied Mechanics, Slovak University of Technology, Rázusova 2, 91701 Trnava, Slovak Republic 


\section{INTRODUCTION}

The production strategy in the second half of the $20^{\text {th }}$ century was characterized by effective exploitation of dedicated machines and automated lines with the aim to achieve to maximum volume yield. The small shortening of production cycle influences the production volume in mass production significantly.

Today market is characterized by the strategy of consumer's individualization. This strategy is oriented very strictly to consumer's requirements, production broadening and shortening of innovation cycle. In addition, the products are made from new materials, they have new shapes and functions. The time and its reduction are the most important parameters in this strategy.

The production strategy focused to time requires the change from traditional functional production structure to a production used flexible manufacturing cells and lines. Production by flexible cells (FMS) is the most important manufacturing philosophy in the last years.

This philosophy is based on the following similarities:

- Similarity of manufactured parts,

- Similarity of process plans.

Recognition of the similarity of manufactured parts allows to assort them to the groups by machines required for its manufacturing. By manufacturing of a single group of parts, economical benefit near to mass production can be achieved.

At the Institute of Production Systems and Applied Mechanics, a model of integrated flexible manufacturing and assembly system for small batch production was built. The model introduces a new philosophy for design of complex manufacturing. This new approach represents a flexible manufacturing system manipulating by workpieces, machining some workpieces for final product and assembling these parts to final product. All operations are realized in one workplace what is different from the traditional manufacturing and assembly systems.

The most important characteristics of this system is that this system employs no external industrial robot for manipulation and/or assembly process (Fig. 1). Exchangeable end effectors for manipulation and assembly are placed at arm of device. Other end effectors are stored in end effectors storage (Fig. 2).

A higher efficiency of this device in comparison with classical flexible manufacturing systems can be expected.

According to this trend, new non-traditional model of integrated flexible manufacturing system for small batch production is introduced. The system is carrying out the manipulation with workpieces and it is machining them for the defined final product or products. Afterwards, these final products are built-up by this system and sent off to storage. 
This conception of manufacturing system is different from the traditional system because it has only one workspace and all manipulations are realized in this workspace including machining and assembly operations without external industrial robots.

Except manipulation and assembly, this device will also perform technological operations like drilling or milling. These technological operations will be performed by special spindle. The spindle would be located on the manipulation equipment of the device. Flexibility of the spindle will be assured by automatic tool changing system.

ree degree of freedom. The manipulated workpiece together with system pallet will weigh less than $3 \mathrm{~kg}$. The manipulator will take this pallet (together with workpiece) to the rotational feeding device (interface device between assembly cell and shelf storage) and give it to shelf storage cell (Fig. 3 ).

Solution of material flow requires to remove the waste as well. For chip exhaustion after machining, the sawdust exhauster FT 200 SF is used. Construction of this mobile sawdust and chip exhauster enables its movement among several machines. The exhauster provides a possibility to line up two exhaust hosepipes, i. e. it enables good chip and sawdust exhaustion from the workplace.

\section{MATERIAL FLOW}

The material flow is one of the most expensive systems into production because it employs the most workers. For high efficiency of production, it is necessary to consider the high-usage of transport ways on base of transported material and the exploitation of single production system devices in the time of the project proposal.

In the next paragraph, the particular factors affected the logistic flow proposal for manufacturing system will be described.

- Transport and handling subsystem is generally one of the most important subsystem of the manufacturing system. It is intended for the transport and manipulation with main and supply material, manufacturing tools (tools and tool holders, fixturing, equipment, scales, carriers and others) and with the waste. Used features of inter-operational transport and handling are dependent on geometrical shape and weight of transported material, parts and tools. Automation of handling in manufacturing system is enabled by technological pallets (holders or another elements with this function, e.g. fixtures). The part is clamped outside a machine workspace onto technological pallet and transported together. The part is positioned and clamped into position for machining. Technological pallet serves at the same time as a transport pallet.

The other objects for transport and handling are production devices representing the needed technological equipment of workstation and they are required for realization of specific operations using a correspondent machine. These objects are transported to workstation in sets or in parts in case when some of them create undetachable part of standard workstation equipment. 
The waste is removed from workstation by transport system specifically designed for this purpose. The transport system for supply material (cooling fluid, lubricant substances and other) is built similarly.

Devices for operational handling are solved modularly. That means that to one machine more types of operational handling devices can be connected according to the type of machined part. Operational handling is controlled by machine control system because it is related to the technological devices performing a technological process. Manufacturing system control is connected to the inter-operational transport and handling.

Storage system is an important part of the flexible manufacturing system. It provides effective entry and storage (holding) of a number of raw products, semi-products, parts, tools and others. To this type of automated storage belongs for example the shelf storage too. The storage capacity and parameters depend on necessary material reserve for fluent production and continuous manufacturing system. Automatic shelf storage contains following main elements:

- Shelf construction,

- Automatic rear or stacker devices,

- Device for palette relocation in container,

- Device for palette transport from container to transport system,

- Technical resources of automatic control system.

Necessary condition for operation of integrated system is integration of materials and information flow; that means for example automated transport and automatic tools exchange.

Production system is characterized by the possibility of processing the arbitrary part from defined groups by given manufacturing procedure while the rebuilt time for a new production task is very short. Primary feature is the flexibility.

\section{MANUFACTURING SYSTEM PLANNING.}

The existing principles of machine plant design become to be improper and a completely new concept of manufacture and control design is gained ground.

The requirements for the new manufacturing system design are as follows:

- Flexibility,

- Productivity,

- Quality.

Requirements set by product to manufacturing space result from product size, mass, type of construction, from its position in manufacturing program structure and production volume. Size and mass of the product determine the needed manufacturing, operating and storage places. Product constructions assign the process of manufacture and the further technologically constraint task sequences which form the base for 
general plant design i.e. the manufacturing device arrangement and space structure formation. Entire plan comprises material, information, power and personal flows.

Signification of particular flows of manufacturing system composition is dependent on the manufacturing process of a given product. In case of transport demanding production, the arrangement of manufacturing centers focused on the materials flows is critical.

Size and mass impose requirements to spaces from the aspect of necessary place. Production space must provide workpiece input and output, supply materials and allows transport device locomotion.

\section{MATERIAL FLOW PLANNING}

Transport and material handling are important part of planning. Transport system must provide material and component transfer between workstations. Handling system connects workstations by transport system. The storage system is assignated for a fluent supply of production by material and tools as well as for equalizing of workstations capacity according to their payload and performance. In principle, this area of manufacturing system employs up to the $25 \%$ of workers, it takes about $55 \%$ of total area and approximately $87 \%$ of time during which the material stays in corporation. Activities included to the transport system create sometimes up to $70 \%$ from general costs per product manufacturing and as well as considerably influence products quality because from 3 to $5 \%$ of material is destroyed during transport and handling due to the incorrect handling. The material flow is organized flow of material (raw material, semifinished products, supply material and wastes).

The base for achievement of high efficiency is the direct and simple material flow which is dependent on the optimal special layout of production and storage facilities and their devices, further on single manufacturing procedures and proper production organization.

The main aim is to design better technical and organizing methods of material flow not only by mechanization and automation of handling operations but also by utilization of suitable information systems.

General procedure of planning of transport, handling and storage system is as follows:

1. Analysis material flows and calculation of traffic system performance,

2. Processing of workshops disposition (layout of producing centers),

3. Analysis of existing devices (transport equipment, auxiliary resources, storage facilities, containers, handling devices),

4. Processing of transport systems variants, handling and storages.

a) Transport system topology,

b) Static dimensioning of materials flow elements (calculations of transport devices, speed parameters, loading capacity, loading and unloading times and others), 
c) Interface between transport system and workstation solution and possibilities of pallet and tools relocation.

d) Processing transport control system, handling and storages.

5. Simulation and dynamic dimensioning of material flow components and optimization of transport, handling and storage system (analysis of narrow places, system lockouts, container sizes, transport and storage devices capacity utilization, control rules).

The analysis of material flows is one of the main subparagraph of material handling analysis.

The rules for effective material handling:

- Creation/selection of the simplest and shortest transport routes,

- Determination of maintenance rhythm, continuity and fluency of material flows,

- Simplification of material handling,

- Design of manufacturing process and layout with regard to the optimal flow of material,

- Assessment of the possibility of the use of material movement due to the gravity,

- Optimizing quantities, size and weight of transferred units,

- Application of mechanization and automation in handling,

- Design all handling, transport and storage activities as the most effective,

- Analysis of handling from the global aspects of the entire corporation

- Evaluation of the possibilities of the use of standard handling devices,

- Achievement of exploitation of transport and handling devices minimally at $60 \%$,

- Accomplishment of ergonomic and safety requirements.

Main features in material flows:

- Transported material,

- Transport, handling and storage units,

- transport equipments, handling devices, storage devices,

- Personnel,

- System of organization and control of transport and storage processes.

In the process of material flow planning, the formula of material flows (Fig. 4) is solved. In the process of material flow planning, it is necessary to consider the fact that the aim of the plan is not the transport and storage of material as these activities are expensive and do not improve the material value. Current systems for handling, transport and storage provide a great number of possibilities for the application of expensive and complex systems. The optimal design should contain minimum storages, transport and handling. Hence, the suitable way before the elaboration of detailed system solution is to reduce mentioned activities to a minimum. It is necessary to take into account a great 
importance of the dependence of material flow and following elements of manufacturing system:

- Workstation and its capacity - incorrectly designed capacities induce unbalance materials flow, cumulation of resources, necessity of buffer stocks, containers and addition handling operations.

- Informational flow and the system controls - proper regulation of manufacturing tasks entering the system, synchronization of purchase, manufacturing and expedition, coordination of manufacturing system control by transport system, while all of them have a significant effect to material flow plan.

All features of manufacturing system must be planned considering mutual interactions and verified by a simulation model before the system realization.

From the point of view of manufacturing and material flow, it is talking about mutual connections and formation of material chain. The main aim is the mutual coordination of all material flows and assurance of the efficiency of material flow between individual segments of a chain.

Objectives for the development and control of optimal material flow chain are:

- Cost saving,

- Powerful capacity along with the minimal resources,

- Short passing through times and minimization of storing times,

- Quick and simple holder motions,

- High flexibility of forwarding and articles quality,

- High level of work and failure minimization,

- High transport and storage quality,

- Humanization of workplaces.

\section{CONCLUSION}

In the last years, the cell manufacturing becomes one of the most important manufacturing types. This conception is based on the relation between manufacturing cell and workpiece. Flexible manufacturing cells allow to manufacture of the small number of parts from the huge range of types and to achieve good economical effects near to large batch or mass production. The manufacturing cells structure enables to connect machines and to save the production time, space and production costs as well. Functions of machines are coordinated and the material flow can be fast.

Manufacturing process of components, parts or final products is usually not realized in single workplace. The manufacturing logistics solves the tasks concerning organization of material and information flow in manufacturing. The importance of manipulating and transport devices is underlined by fact that more than $50 \%$ of time needed for manufacturing is spent by manipulation and transport. Automation level of these processes is generally smaller than automation level of technological processes. 


\section{ACKNOWLEDGMENT}

The research has been supported by VEGA MS and SAV of the Slovak Republic within the project No. 1/3193/06 - Multifunctional manufacturing and assembly cell.

\section{REFERENCES}

[1] Koštál, Peter; Hrušková, Erika; Velíšek, Karol: Clamping fixture for flexible manufacturing cell. Academic Journal of Manufacturing Engineering. No. 2 (2007), pp. 61-64 ISSN 1583-7904.

[2] Velíšek, Karol; Koštál, Peter; Javorová, Angela: Flaxible assembly cell. Proceding of 4th International conference ICAMaT 2005, Editor: C. Doicin, pp.479-482, ISBN 973-27-1254-6, 3. - 4. november, 2005, Bucharest, Romania, The Publishing House of Romanian Academy

[3] Mudriková, Andrea; Koštál, Peter; Velíšek, Karol: Material and information flow in flexible manufacturing cell. In: Annals of DAAAM and Proceedings of DAAAM Symposium. - ISSN 1726-9679. - Vol. 18, No. 1. Annals of DAAAM for 2007 \& Proceedings of the 18th International DAAAM Symposium "Intelligent Manufacturing \& Automation: Focus on Creativity, Responsibility, and Ethics of Engineers" : Croatia, Zadar 24-27th October 2007. - Vienna : DAAAM International Vienna, 2007, s. 485-486

[4] Velíšek, Karol; Javorová, Angela, Zvolenský, Radovan; Danišová, Nina; Koštál, Peter: Multifunctional Manufacturing and Assembly Systém. Poznan Univerzity of Technology, Project Cll-PL-0033-01-0506

[5] Chromjaková, F.: Projektovanie materiálového toku, (Material flow planning) online <:http://www.ipaslovakia.sk/slovnik_view.aspx?id_s=13>, 29.4.2007

[6] Chromjaková, F.: Projektovanie výrobných systémov (Manufacturing system planning), online <:http://www.ipaslovakia.sk/slovnik_view.aspx?id_s=13>, 29.4.2007

[7] Drstvenšek, Igor, Pahole, Ivo, Balič, Jože. A model of data flow in lower CIM levels. J. mater. process. technol.. [Print ed.], Dec. 2004, vol. 157/158, str. 123130. http://dx.doi.org/10.1016/j.jmatprotec.2004.09.010

[8] Drstvenšek, Igor, Pahole, Ivo, Kovačič, Miha, Balič, Jože. Intelligent interface in a flexible production environment. J. mater. process. technol.. [Print ed.], 15. maj 2005, vol. 164-165, str. 1309-1316.

http://dx.doi.org/10.1016/j.jmatprotec.2005.02.074. 


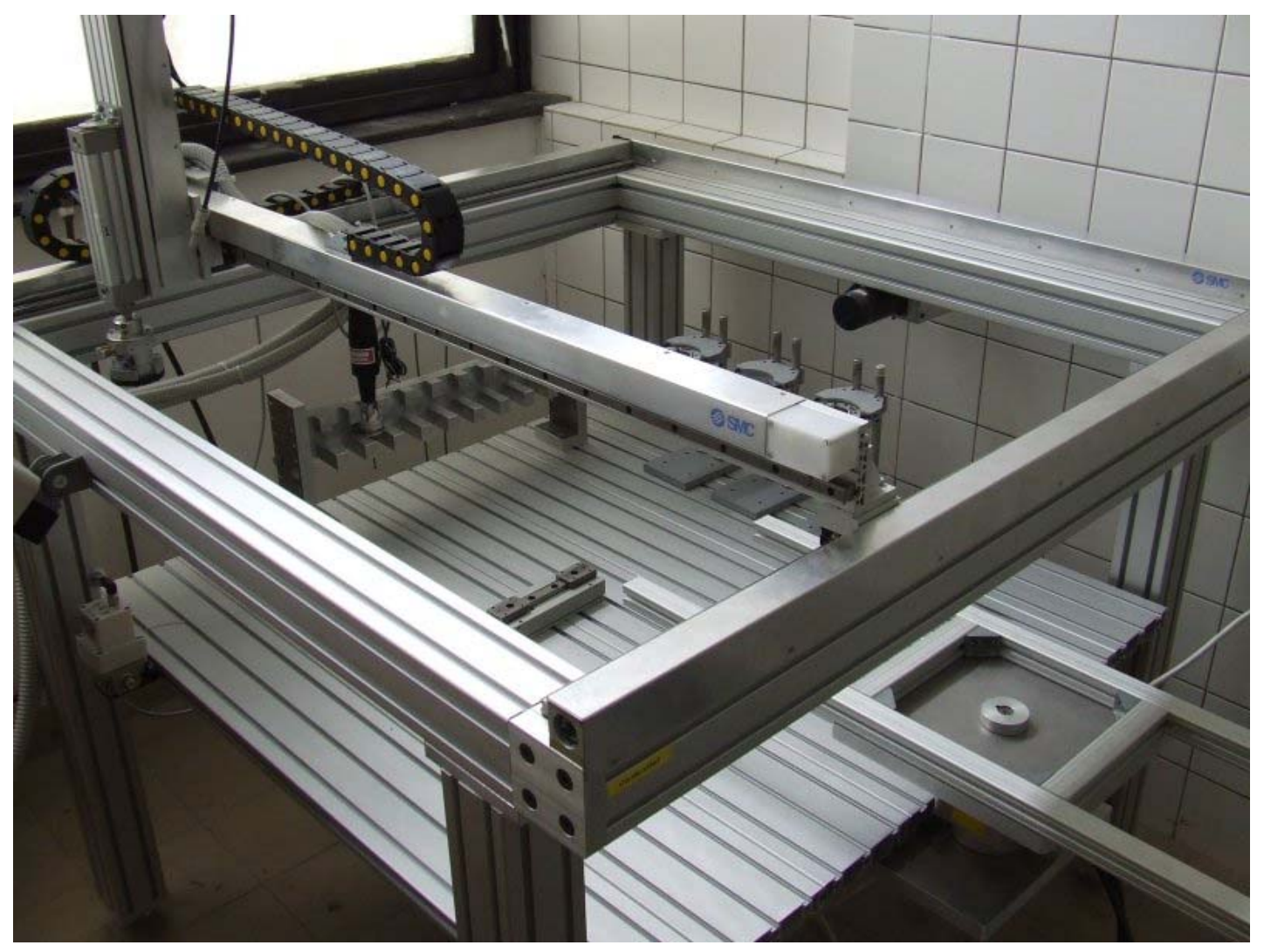

Fig. 1 Flexible manufacturing cell

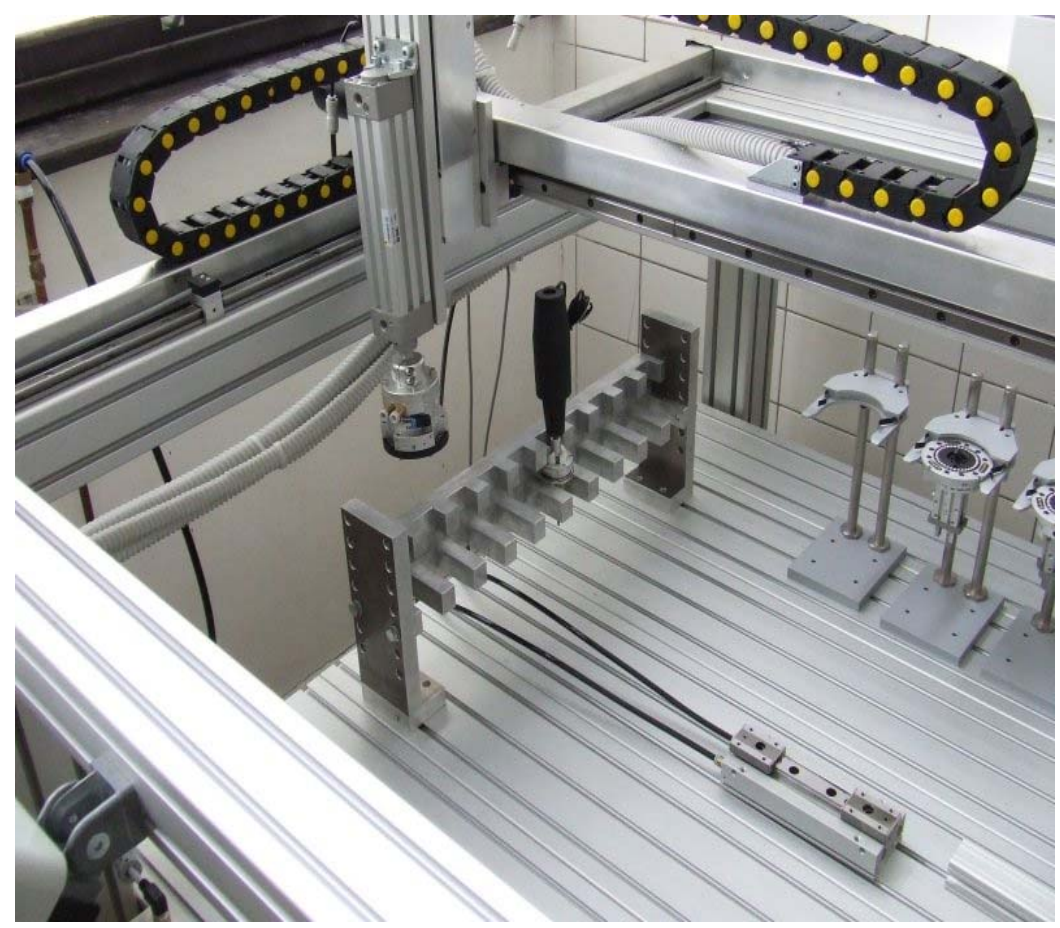

Fig. 2 Tool and griper changing system in flexible manufacturing cell 


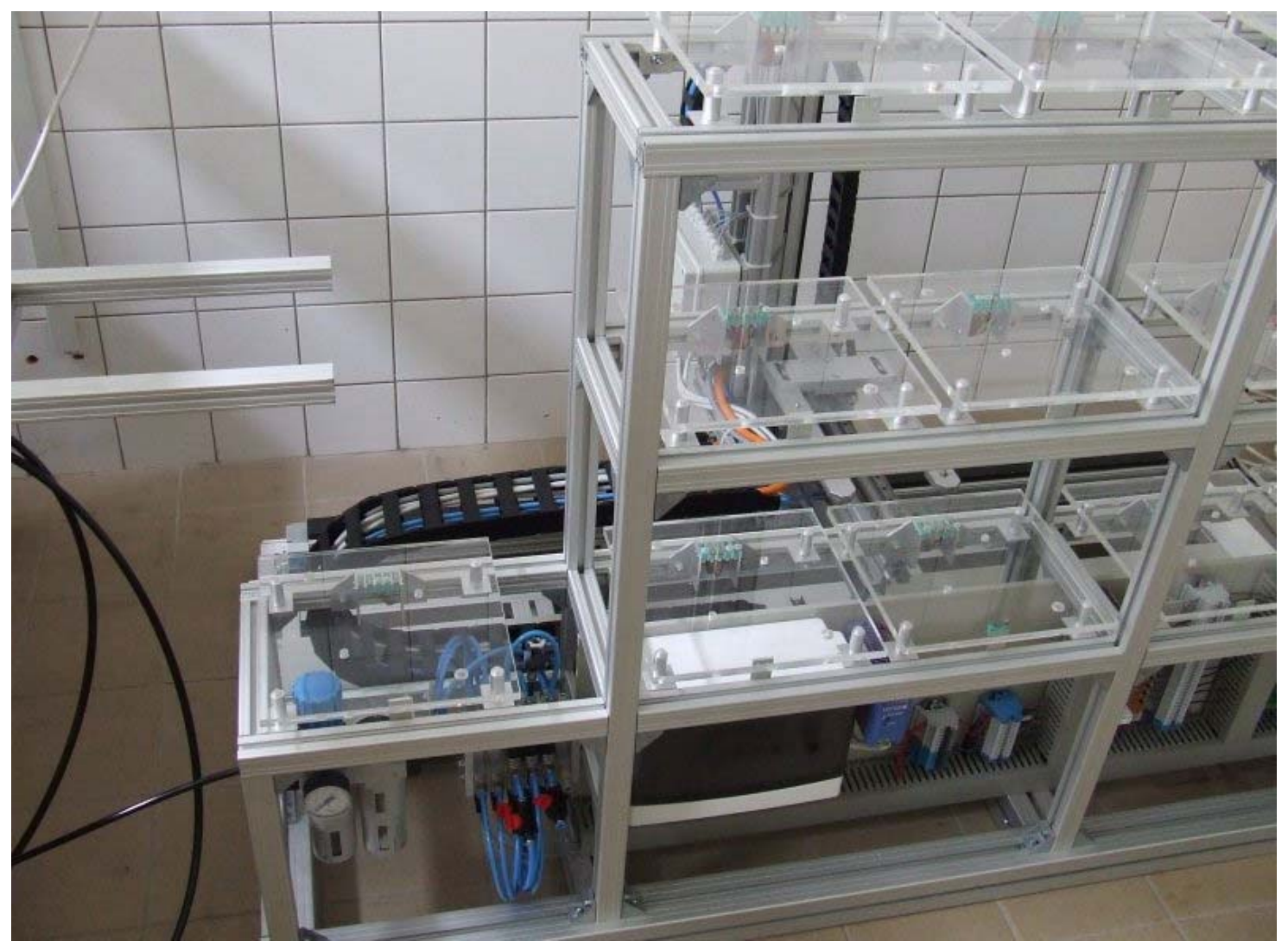

Fiq. 3: Shelf storaqe system

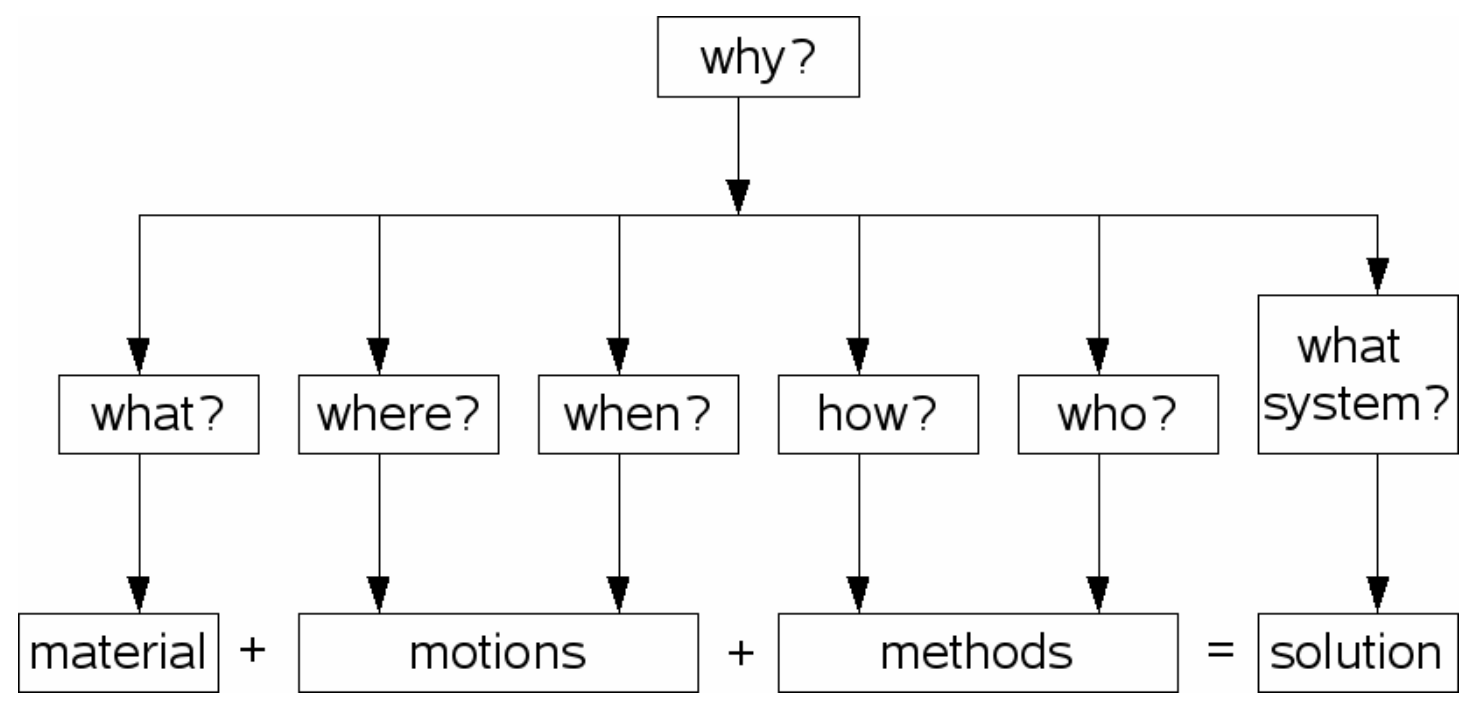

Fig. 4: Formula of material flow 